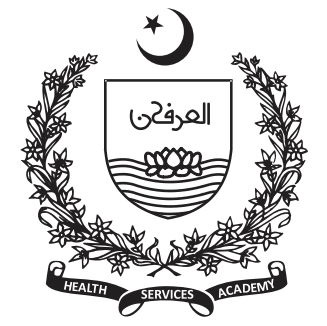

${ }^{1}$ Health Services Academy, Islamabad

Corresponding Author: Yasmeen Anwer yasmeenanwer56@gmail.co $\mathrm{m}$

\section{Resources for Preventing and Responding to Violence Against Children in Islamabad Capital Territory Pakistan}

\author{
Yasmeen Anwer ${ }^{1}$, Fahad Abbasi ${ }^{1}$, Abdullah Hafeez ${ }^{1}$, Siham Sikander ${ }^{1}$, \\ Assad Hafeez ${ }^{1}$
}

\begin{abstract}
Violence against children (VAC) is a serious problem with many millions of children being affected globally with serious health, social, and economic consequences. WHO has published an evidence-based framework (INSPIRE: Seven strategies to end Violence against Children), suggesting that prevention and effective response to VAC can be achieved through strategies directed at changing and modulating certain determinants. INSPIRE identifies 1) implementation of laws, 2) changing norms \& values, 3) safe environments, 4) parent and caregiver support, 5) income and economic strengthening, 6) response and support services, and 7) education \& life skills as areas where efforts can yield maximum impact. Our objective was to review the literature on available resources in the capital of Pakistan (Islamabad Capital City) to establish current state of affairs in terms of prevention and response to VAC.
\end{abstract}

Resources for prevention and response to VAC according to the INSPIRE framework are discussed. We have found that laws are mostly ambiguous, implementation is rare; norms promote early and arranged marriages for girls, allow corporal punishment and child labor, shun all dialogue around sex and sexuality, and overtly prefer male offspring; many children live and work on the street; no large-scale programmes for parent and caregiver support to improve prevention and response to VAC were found; some income support programmes exist but they are unlikely to be organized or integrated with other services; some response and support services were found from both the public and private sectors, yet their effectiveness has not been established; life skill programmes are announced but even among the expensive private schools, only a few teach life skills. Although estimated to be high, there is no official data available on VAC, therefore the quantum of the problem cannot be ascertained.

All relevant sectors will have to collaborate to bring about meaningful progress in child protection, prevention of VAC, and wellbeing of children. Preventive interventions and trauma-informed care by the health-sector are urgent needs. Formation of a central body for children's affairs can ensure exclusive budget allocation to address child-specific issues, co-operation and collaboration from all concerned, and community and stakeholder participation. A comprehensive information system, effective large-scale interventions, and context-specific research are required to improve the state of available resources. 


\section{Introduction}

$\mathrm{O}$ ne billion of the world's children between 2 to 17 years have experienced some form of violence in the last 12 months $(1,2)$. Physical, psychological, and sexual Violence Against Children (VAC) occurs as maltreatment and bullying; trafficking, Interpersonal and Intimate Partner Violence, and even homicide (1). VAC can be perpetrated by caregivers, strangers, \& other children in myriad settings e.g. school, home, street etc. (1). Globally, homicide is one of the top 5 causes of death in adolescents, with boys being the perpetrators and victims $80 \%$ of the times (1). Girls are disproportionately the victims of sexual and emotional violence, with every 1 in 3 girls in the world between the ages of 15 to 19 having experienced abuse by a husband or intimate partner (1). Children living in unsafe environments such as the streets and disaster afflicted regions are more likely to be abused than others (1). Social status of children, cultural norms, little or no education of parents and caregivers, witnessing domestic violence, and poverty are important determinants of VAC $(1,3)$. Sexual violence has long been an established causal factor for psychological, interpersonal, and social issues later in life, and now association of non-sexual violence against children with high risk behaviors e.g. drug use and unsafe sex, mental disorders, suicide attempts, and Sexually Transmitted infections, especially during adolescence has also been found $(4,5)$. The effects of VAC are not just behavioral in nature as exposure to adversity in early childhood causes significant structural changes in the brain, leading to eventual neuropsychiatric and cognitive dysfunction $(6,7)$. Developmental delays can be seen as early as at 18 months of age in children having been exposed to adversity (8).

Not only is it every child's birthright to be free of all forms of violence, VAC also needs to be prevented to avoid the pervasive harm it causes through social and economic setbacks $(1,6)$. As the understanding of VAC as a major cause of physical, mental, \& social health issues throughout the life course increases, so does the urgent need for an effective Public Health response (1).

The Evidence for Better Lives Study (EBLS) by the University of Cambridge is a birth cohort, which aims to study the effects of a child's exposure to violence and other adversities, and its impact on child development and emergence of mental health problems. In each of the eight EBLS sites across the world, EBLS will be accompanied by efforts to introduce multi-sectoral prevention packages that can help children achieve their full potential (9). A Needs and Resource Assessment (NaRA) was performed in the EBLS sites, including Islamabad Capital Territory Pakistan. This assessment followed the INSPIRE framework of WHO for preventing and responding to VAC. INSPIRE outlines seven evidence-based strategies which have shown to be effective. These are: 1- Implementation and Enforcement of laws; 2- Norms and values; 3- Safe environments; 4- Parent and caregiver support; 5- Income and economic strengthening; 6-Response and support services; and 7- Education and life skills (1).

\section{Methodology}

Our paper is based on the NaRA we performed in 2018, and further review of available information on the resources for preventing and responding to VAC in Pakistan. Literature was searched for studies, articles, and papers which included discussion on child abuse in the context of prevention and response. Grey literature was incorporated for information on available resources. We searched for scientific literature on PubMed and Google Scholar, used GOALI for research papers on Laws and Policy, Google Scholar for Social Sciences, and Google.com for grey literature.

Limitations: Our assessment aimed to have an overview of the needs \& resource situation, and is based on secondary data for the most part. A full-scale mapping exercise is recommended. Moreover, our review is limited by the paucity of robust data due to unavailability of information systems, underreporting, weak legislation, and variability of rules and regulations.

\section{Context:}

Pakistan is the $6^{\text {th }}$ most populous country in the world with a population of 207 million and an annual growth rate of $2.4 \%$ (10). Human Development Index of Pakistan is $0.562 ; 150^{\text {th }}$ in the world (11). When adjusted for inequality it falls to 0.387 (11). GNI Per capita is $\$ 5311$ (11); Average Life expectancy at birth is 66.6 year; on the average children receive 5.5 years of schooling (11); Gender Inequality index, at $134^{\text {th }}$ in the world, is 0.541 (11).

Between $37.6 \%$ \& $40.2 \%$ of Pakistan's children under the age of 5 years are stunted $(10,12) .36 .9 \%$ of 
households are food insecure in Pakistan (12). Neonatal mortality is one of the highest in the world at 42/1000; 62 out of every 1000 children die in the first year of life; 74-75 out of 1000 before reaching 5 years (10). An estimated 22.8 million children between 5-16 are out of school, over 11 million children are engaged in labor (13). Net Attendance Ratio (NAR) is 59\% at primary level and $38 \%$ at the middle/secondary level (10). In 2018, 3832 cases of child sexual abuse were reported from across Pakistan; of these about 55\% were girls. 115 of these cases occurred in Islamabad Capital Territory (14).

Islamabad Capital Territory (ICT) is the Federal Capital of Pakistan with a population of 2,001,579 with almost equal distribution between urban and rural population at $1,009,832$ vs. 991,747 (15). There's a sharp class-divide between the urban and rural (and semi-rural) populations with the urban populace enjoying a higher quality of life.

Findings:

1- Implementation and Enforcement of laws

The INSPIRE Handbook suggests that laws banning violent punishment of children, criminalizing sexual abuse and exploitation of children, preventing alcohol misuse, \& laws that limit youth access to firearms and other weapons, are among those which can prevent VAC (16). For the purposes of our review we have focused on the first three.

Pakistan is signatory to many international commitments, the UNCRC being the most important as it is the basis of national policy for the rights of children (17). The National Commission on the Rights of Children (NCRC) is the central body for policy making for child protection (17). A legislation, ICT Child Protection Act, was approved in February 2018, which directed the formation of a Child Protection Advisory Board in ICT (18). This act identifies "children in need of care", and instructs Child Protection Centers to be built for these children. The law details the steps to be taken by its appointed agents, and defines the role of Law Enforcement Agencies and courts (18).

A bill for Prohibition of Corporal punishment in ICT has been proposed and approved by the lower house of the senate; It's enactment pending (19). However, the proposed legislation is only against violent discipline in schools and seminaries and does not cover the home and other non-institutional settings (20). In April 2019, The Zainab Alert, Response, and Recovery Act 2019 was proposed as a flag-and- response system for missing children (21). This bill is now approved and enacted. A recently proposed amendment in the marriage law which prohibits girls to be married before the age of 18 awaits approval (22). Sale and consumption of alcohol is restricted in Pakistan by law.

2-Norms \& Values:

\begin{tabular}{|c|c|}
\hline $\begin{array}{l}\text { Current Norms } \\
\text { \& Practices in } \\
\text { Pakistan }\end{array}$ & Description \\
\hline $\begin{array}{l}\text { Corporal } \\
\text { Punishment }\end{array}$ & $\begin{array}{l}\text { In } 201776 \% \text { of children in Pakistan } \\
\text { were reported to have experienced } \\
\text { psychological aggression; } 66 \% \\
\text { physical punishment; } 31 \% \\
\text { experienced severe physical } \\
\text { punishment (23). A survey in } \\
\text { Pakistan found that 44\% of } \\
\text { students between } 12-17 \text { years had } \\
\text { experienced physical violence in } \\
\text { the last } 6 \text { months (24); } 30 \% \text { had } \\
\text { been locked in a toilet by a teacher } \\
\text { (24). No action was taken in } \\
2 / 3 r d s \text { of the reported cases. } \\
\text { Teachers believed that corporal } \\
\text { punishment is necessary for good } \\
\text { academic performance (24). } \\
\text { Another study in } 2013 \text { found } 84 \% \\
\text { parents and } 75 \% \text { teachers agreeing } \\
\text { teachers were justified in beating } \\
\text { students who were rude and } \\
\text { disobedient. } 85 \% \text { of parents } \\
\text { believed that children who stole } \\
\text { "deserved" physical punishment } \\
\text { (25). }\end{array}$ \\
\hline Child Lal & $\begin{array}{l}\text { There are an estimated } 11-12 \\
\text { million children who work as } \\
\text { labourers in Pakistan, } 50 \% \text { are } \\
\text { younger than } 10 \text { years of age. In } \\
\text { ICT, } 10739 \text { children from the slum } \\
\text { areas work as labourers, } 39 \% \text { of } \\
\text { them between the age of } 11-15 \\
\text { years (26). Children are seen } \\
\text { cleaning windshields on traffic } \\
\text { signals, selling toys, working in } \\
\text { hotels and auto workshops, and } \\
\text { doing other menial jobs (26). Every } \\
\text { fourth house in ICT employees a } \\
\text { child for domestic labour (27). }\end{array}$ \\
\hline Bonded Labour & Bonded labour, especially in brick \\
\hline
\end{tabular}




\begin{tabular}{|c|c|}
\hline & $\begin{array}{l}\text { kilns, has been an established } \\
\text { problem for Pakistan. Children as } \\
\text { part of their families are indebted } \\
\text { to the kiln (or another } \\
\text { establishment e.g. farm's) owners } \\
\text { and work their whole lives } \\
\text { repaying a never-ending debt, } \\
\text { suffering a life of poverty, slavery, } \\
\text { and destitution (26). }\end{array}$ \\
\hline Early Marriages & $\begin{array}{l}\text { It is expected that girls should be } \\
\text { married as early as possible. } \\
\text { "Good girls" are expected to } \\
\text { accept their parents' decisions and } \\
\text { it's the job of a respectable girl to } \\
\text { contribute to the husband's } \\
\text { household in moral, intellectual, } \\
\text { and physical ways, including } \\
\text { doing domestic work and } \\
\text { satisfying the husband's urges } \\
\text { (28). Religion, family honour (fear } \\
\text { of promiscuity), and tradition play } \\
\text { strongly into the issue of early } \\
\text { marriages (28). }\end{array}$ \\
\hline $\begin{array}{l}\text { Violence in the } \\
\text { name of honour }\end{array}$ & $\begin{array}{l}\text { Watta-satta (bride-exchange } \\
\text { between two families, is common } \\
\text { in Pakistan) (28). Maiming and } \\
\text { killing for "honour" is considered } \\
\text { justified by many. Violent crimes } \\
\text { in the name of honour are typically } \\
\text { perpetrated by close family } \\
\text { members (29). Informal and } \\
\text { parallel justice systems exist which } \\
\text { punish "honour crimes" severely, } \\
\text { and even use sexual punishment } \\
\text { aimed at women and girls for a } \\
\text { male relative's crimes (29). }\end{array}$ \\
\hline $\begin{array}{l}\text { Juvenile Justice } \\
\text { System }\end{array}$ & $\begin{array}{l}\text { There is no jail in Islamabad. The } \\
\text { juvenile offenders are housed in } \\
\text { Rawalpindi's Adiala Jail, where } \\
5000-10000 \text { inmates live against a } \\
\text { capacity of } 3000 \text { prisoners. The } \\
\text { number of juvenile offenders in } \\
\text { ICT is hence reflected in Punjab's } \\
\text { statistics (26). }\end{array}$ \\
\hline $\begin{array}{l}\text { Taboos around } \\
\text { Sexual \& } \\
\text { Reproductive } \\
\text { Health }\end{array}$ & $\begin{array}{l}\text { Sex-education remains } \\
\text { controversial in Pakistan with } \\
\text { tradition causing reluctance in } \\
\text { bringing up the topic. A study of } \\
460 \text { school children, } 4-14 \text { years old, } \\
\text { found that } 197 \text { of them had been }\end{array}$ \\
\hline
\end{tabular}

\begin{tabular}{|l|l|}
\hline & $\begin{array}{l}\text { fondled and 16 had been victims of } \\
\text { child pornography. The issue of } \\
\text { child sexual abuse remains buried } \\
\text { in secrecy (30). } \\
\text { A study conducted with girls aged } \\
\text { 16-18 in an urban centre found no } \\
\text { participant who understood the } \\
\text { concept of Reproductive Health, } \\
\text { few saw benefits in learning about } \\
\text { sex, safe-sex, and reproductive } \\
\text { health until after marriage. Only a } \\
\text { few seemed open to the discussion } \\
\text { on these matters as they are } \\
\text { considered inappropriate for } \\
\text { unmarried girls in Pakistan (31, } \\
\text { 32). }\end{array}$ \\
\hline $\begin{array}{l}\text { Preference are expected to support their } \\
\text { male offspring } \\
\text { parents in old-age so male children } \\
\text { are seen as economic and social } \\
\text { assets. Cultural preference for } \\
\text { males in a resource-scarce setting } \\
\text { leads to increased intensity of } \\
\text { discrimination. Girl children are } \\
\text { not deemed worthy of investments } \\
\text { as they will become brides to other } \\
\text { households ("other people's } \\
\text { property") and will not bring } \\
\text { returns to the parents (33). }\end{array}$ \\
\hline
\end{tabular}

The INSPIRE Handbook identifies three tiers of interventions which may help to prevent VAC: small group programs, community mobilization, and bystander interventions (16).

The Ministry of Human Right's Action Plan 2016 includes public awareness campaigns to sensitize the public about human rights including child rights. The campaign includes strategy for mass media, workshops, seminars, and conferences for behavioral change, and the mandatory study of subjects of Human Rights interests throughout the academic span of a student (34). Child Protection Committees being formed in the slum areas of Islamabad by the National Child Protection Centre (NCPC) is an attempt to mobilize communities for affecting change in norms (35).

\section{3- Safe Environments:}

NCPC in ICT plans on mapping ICT for identifying "hotspots" where child protection is urgently required, provision of temporary shelter, counseling, 
referral and rehabilitation mechanisms in line with the Child Protection Act 2018 of ICT (35). WHO outlines identifying "hotspots" as one of the approaches to provide safe environment to children. Other suggested approaches are having safe built environments and interrupting the spread of violence through training credible members of communities (16).

\section{4- Parent \& Caregiver Support:}

The objective is to help parents protect their children, discourage harsh parenting practices, and create positive relationships between parents and children. Parenting groups, home-visiting programs, and comprehensive social and educational programs which include prevention of VAC in their agenda, are some of the evidence-based interventions in this regard (16). Ministry of Human Right's Action Plan 2016 addresses the last approach (34).

\section{5- Income and economic strengthening:}

The INSPIRE Handbook lists cash transfers, group savings and loans, and microfinance (combined with gender-norms/equity training) ad promising approaches to provide economic strengthening to families (16).

Pakistan Bait-ul-Maal (PBM), an autonomous financial institution, assists the vulnerable segments of the society including children (36).

Child Conditional Cash Transfer (CCCT) is a nationwide, state-run program, linked with unconditional cash transfers of Benazir Income Support Program (BISP). Parents selected from BISP database are provided with cash transfers to send their children to school. The Gallup survey 2010 found this program to have increased primary school enrollment by $11.65 \%$ (36).

The recently announced government-lead "Ehsas" program undertakes to assist the most deprived sections of the society. Its interventions include a proposition to change the constitution so that food, clothing, shelter, medical care, and education of the poor to be the responsibility of the state; an extensive social safety net program, a labor and farmer's program, a woman's empowerment plan, housing schemes for joint ownership for the poor, education funds, and improvement in technical certifications (37). Comprehensive implementation is awaited.

6- Response \& support Services:
The INSPIRE handbook mentions Clinical inquiry \& intervention, counselling, foster care, \& treatment programs as examples of evidence-based approaches for resources and support mechanisms (16). The National Child Protection Centre (NCPC) provides services of shelter, reunion, counselling, legal aid, and referral to children who have suffered violence in ICT. A round-the-clock helpline at 080011515 is set up to respond to calls concerning children who need immediate protection (35). Development of a Child Protection Information System by the NCPC in ICT is underway. Pakistan Sweet Homes (PSH), a network of shelter houses for orphans, provides the children with food, clothes, and education in addition to a place to live. There are 10 PSH shelters in ICT (36).

According to news reports, a "Women and Child Protection Center" has been established in the Women Police Station in ICT, which has its own mobile vehicle and a response time of 5-7 minutes (38). Sahil, an NGO in ICT, provides free legal counselling and representation to victims of child sexual abuse (CSA), a teachers' training program for improving prevention and reporting of CSA, counselling, and awareness campaigns (14) SPARC, another NGO, offers shelter to street children, training workshops on child rights, works with juvenile offenders, and runs campaigns against early/child marriage (27). An Office of National Commissioner for Children in ICT functions with UNICEF for receiving complaints from children and their caregivers about maladministration of government agencies. This office looks into systemic issues, takes action, and shares information with stakeholders (26).

\section{7-Education \& Life Skills:}

Ministry of Federal Education and Professional Training Islamabad, in 2017, published a revised National Curriculum for Early Childhood Care and Education (NECCE) "aimed to develop indicators in early childhood care and education to cultivate an environment where children learn pro-social behaviors helping them to learn through collaborative processes, cooperation, sharing and caring for others". The focus of the curriculum designed for 04-05- yearolds is on developing life skills (39).

National Centers for Rehabilitation of Child Labor (NCsRCL) is a program for educating and assisting children 5-14 years who are involved in labor (36). NCPC provides non-formal educational, vocational training, and medical aid to run-away, homeless, and lost children, as well as to children who beg. A school 
is built inside the NCPC premises to offer education to needy children $(26,33)$.

\section{Conclusion}

Our review foremost established a dearth of data on the resources for prevention of VAC in ICT. A coherent set of laws for prevention and response in ICT is missing. The existing laws do not address VAC comprehensively, with unclear definitions of maltreatment, abuse, etc. Laws are not enforced due to multiple systemic issues. There's no official data to guide policy, resource allocation, and programs. More significantly, no funds are ear-marked for children in the budget.

No information system for VAC could be found. Resources for child protection and prevention of VAC are few, weak, and inaccessible to people. Reporting, when it does occur, is usually through LEAs who have poor processes to address needs. No standardized mechanism for clinical inquiry \& intervention, traumainformed care, and reporting in healthcare settings was found. Available programs fall short in coverage, accessibility, and sustainability. No resources are available for parent and caregiver support. Life-skills development and education in the backdrop of poverty and inequity is all but absent. Communitybased programs for prevention of VAC weren't found. Large-scale research into the issue is missing.

As evidenced by the nature of strategies in the INSPIRE framework, VAC is multi-sectoral problem, and no solution can be effective unless it is based on an integrative model of collaboration between concerned sectors. Stakeholder and community participation is key to success. We suggest that VAC does not exist in isolation and major shifts in paradigm and policy are required to change the condition of children in Pakistan. Pakistan has 48.75\% of its population under the age of 18 years (40); a veritable pool of potential; hence it stands to reason that this demographic bulge be given the highest consideration and priority. We recommend that a model central body for the affairs of children is formed in ICT, comprising of representatives of all relevant sectors (e.g. education, legislation, health, law enforcement etc.) with its own budgetary allocation.

More specifically for VAC, the health sector should take the lead and view it as a priority for prevention and trauma-informed response interventions; as healthcare workers are often the first, and sometimes the only ones, to whom cases of VAC are reported. There is a need to define VAC and have clear \& comprehensive policy on the issue. Sustainable programs addressing safety for children under all settings, with improved coverage, need to be developed and implemented. Existing programs for prevention, response, and support for VAC should be integrated into other social welfare programs. There is a need for a functional, sustainable, and reliable system of monitoring and evaluation for all public and private programs addressing VAC directly or indirectly. Lastly, there is a dire need for research to develop evidence-based multi-sectoral policies and interventions for prevention of VAC.

\section{References:}

1. World Health Organization. INSPIRE: Seven Strategies for Ending Violence Against Children [Internet]. Luxemburg: World Health Organization; 2016 [cited 2019 Aug 23]. Available from: https://apps.who.int/iris/bitstream/handle/10665/20 7717/9789241565356-

eng.pdf;jsessionid=CDEF0B0CF48C19DFEF8BE77C144E 5B36? sequence $=1$.

2. Hillis S, Mercy J, Amobi A, Kress H. Global Prevalence of Past-year Violence Against Children: A Systematic Review and Minimum Estimates. Pediatrics. 2016;137:e20154079-e.

3. Ali NSMF, Ali FNM, Khuwaja AKMF, Nanji KBB. Magnitude and factors associated with child abuse in a mega city of developing country pakistan. Iran J Pediatr. 2014;24(2):140-6.

4. London S, Quinn K, Scheidell JD, Frueh BC, Khan MR. Adverse Experiences in Childhood and Sexually Transmitted Infection Risk From Adolescence Into Adulthood. Sexually transmitted diseases. 2017;44:52432.

5. Norman RE, Byambaa M, De R, Butchart A, Scott J, Vos T. The Long-Term Health Consequences of Child Physical Abuse, Emotional Abuse, and Neglect: A Systematic Review and Meta-Analysis. PLoS Medicine. 2012;9.

6. Felitti VJ, Anda RF, Nordenberg D, Williamson DF, Spitz AM, Edwards V, et al. Relationship of Childhood Abuse and Household Dysfunction to Many of the Leading Causes of Death in Adults: The Adverse Childhood Experiences (ACE) Study. American Journal of Preventive Medicine. 2019;56(6):774-86.

7. Lim L, Hart H, Mehta M, Worker A, Simmons A, Mirza $\mathrm{K}$, et al. Grey matter volume and thickness abnormalities in young people with a history of 
childhood abuse. Psychological Medicine. 2018;48:103446.

8. Bhopal S, Roy R, Verma D, Kumar D, Avan B, Khan B, et al. Impact of adversity on early childhood growth \& development in rural India: Findings from the early life stress sub-study of the SPRING cluster randomised controlled trial (SPRING-ELS). PloS one. 2019;14:e0209122-e.

9. University of Cambridge, Violence Research Centre. Evidence for Better Lives Study (EBLS) [Internet]. University of Cambridge; [cited 2019 August 22]. Available from: https://www.vrc.crim.cam.ac.uk/vrcresearch/EBLS.

10. National Institute of Population Studies Pakistan, ICF International. Pakistan demographic and Health Survey 2017-18 [Internet]. Islamabad, Pakistan Rockville, Maryland, USA2019 [cited 2019 Aug 5]. Available from: http://nips.org.pk/abstract_files/PDHS 2017-18 - key findings.pdf.

11. United Nations Development Programme. Human Development Indices and Indicators: 2018 Statistical Update [Internet]. United Nations Development Fund; 2017 [updated 2018; cited 2019 Aug 23]. Available from: http://hdr.undp.org/sites/all/themes/hdr_theme/cou ntry-notes/PAK.pdf.

12. UNICEF, Government of Pakistan. National Nutrition Survey 2018: Key Findings Report [Internet]. Pakistan: UNICEF Pakistan; 2019 [updated 2019 June 11; cited 2019 Aug 23]. Available from: https://www.unicef.org/pakistan/reports/nationalnutrition-survey-2018-key-findings-report.

13. United Nations Children's Fund. Pakistan Annual Report 2016 [Internet]. Islamabad, Pakistan: United Nations Children's Fund (UNICEF) Pakistan; 2017 [cited 2019 Aug 5 ]. Available from: https://www.unicef.org/pakistan/reports/annualreport-2016.

14. Sahil. Cruel Numbers 2018 [Internet]. Pakistan: Sahil; 2019 [cited 2019 Aug 23]. Available from: http://sahil.org/cruel-numbers/.

15. Pakistan Bureau of Statistics. Block Wise Provisional Summary Results of 6th Population \& Housing Census2017 [As on January 03, 2018] [Internet]. Pakistan2017 [updated 2019 August 2; cited 2019 Aug 5]. Available from: http://www.pbs.gov.pk/content/populationcensus.

16. World Health Organization. INSPIRE Handbook: Action for Implementing the Seven Strategies for Violence Against Children [Internet]. Geneva: World Health Organization; 2018 [updated 3 August 2019; cited 2019 Aug 23]. 297]. Available from: https://www.who.int/violence_injury_prevention/viol ence/inspire-package/inspire-handbook/en/.

17. Jabeen T. Pakistan's Child Protection Legislative and Policy Frameworks: A Critical Review. Pakistan Journal of Criminology. 2013;5(2):159.
18. Islamabad Capital Territory Child Protection Act 2018 Stat. F.9(4)/20I 8-Legis (May 24 2018).

19. Prohibition of Corporal Punishment Bill 2016, Senate (2017 Feb 20).

20. Global Initiative to End All Corporal Punishment of Children. Corporal punishment of children in Pakistan [Internet]. Pakistan: Global Initiative to End All Corporal Punishment of Children; 2018 [updated December 2018; cited 2019 Aug 21]. Available from: http://www.endcorporalpunishment.org/wpcontent/uploads/country-reports/Pakistan.pdf.

21. Zainab Alert, Response, and Recovery Act, National Assembly(2019).

22. Child Marriage Response (Amendment) Act 2019, National Assembly(2019).

23. United Nations Children's Fund, Pakistan. 2018 Annual Report, Pakistan [Internet]. Pakistan: United Nations Children's Fund (UNICEF) Pakistan; 2019 [cited 2019 Aug 22]. Available from https://www.unicef.org/pakistan/media/2021/file/A nnual Report 2018 Revised Final.pdf.

24. International Center for Research on Women, Plan International. Are Schools Safe and Gender Equal Spaces [Internet]. International Center for Research on Women (ICRW) and Plan International; 2014 [cited 2019 Aug 5]. Available from: https://www.icrw.org/wpcontent/uploads/2016/10/ICRW_SRGBV-Report-2015.pdf.

25. Plan International. Why Do Teachers Use Corporal Punishment in Schools [Internet]. Pakistan: Institute of Social Sciences; 2013 [updated April 2013; cited 2019 Aug 23]. Available from: https://www.academia.edu/30259344/Why_do_Teach ers_use_Corporal_Punishment_in_Schools.

26. Office of the National Commission for Children, Pakistan. The State of Children in Pakistan [Internet]. Islamabad, Pakistan: Office of The National Commission for Children; 2015 [cited 2019 Aug 23]. Available from: http://www.mohtasib.gov.pk/images/pdfs/SOCP.pdf

27. Society for the Protection of the Rights of the Child. SPARC [Internet]. Pakistan: Society for the Protection of the Rights of the Child; [updated 2019; cited 2019 Aug 23]. Available from: https://www.sparcpk.org/index.html.

28. Veen S, Moorten R, Durani W. Marriage DecisionMaking: A family affair-Insight into marriage decisionmaking processes and social norms around child marriage in Larkana and Shikarpur in Sindh and Lodhran and Muzaffargarh in Punjab, Pakistan [Internet]. The Hague, The Netherlands: Oxfam Novib; 2018 June [cited 2019 Aug 23]. Available from: https://oxfamilibrary.openrepository.com/bitstream/h andle/10546/620535/rr-marriage-family-affair-socialnorms-210618-en.pdf? sequence $=2 \&$ is Allowed $=y$. 
29. Amnesty International. Amnesty International Report 2017/18 [Internet]. London,

United Kingdom: Amnesty International Limited; 2018 [cited 2019 August 5]. Available from: https://www.amnesty.org/en/countries/asia-and-thepacific/pakistan/report-pakistan/.

30. Ain NE. Prevention of Child Abuse Through Awareness and Curriculum Design. Psychology Research. 2017;7:112-8.

31. Bashir Q, Usman A, Amjad A, Amjad U. 'The Taboo that Silences': Awareness about Sexual and Reproductive Health Issues among Adolescent Females during Pubertal Transition.

32. Fikree FF, Pasha O. Role of gender in health disparity: the South Asian context. BMJ (Clinical research ed). 2004;328:823-6.

33. Pulla VR, Tarar MG, Ali MA. Child Protection System and Challenges in Pakistan. Space and Culture, India. 2018;5:54.

34. Ministry of Human Rights, Pakistan. Action Plan For Human Rights [Internet]. Islamabad, Pakistan: Ministry of Human Rights, Pakistan; 2016 [cited 2019 Aug 6]. Available from: http://www.mohr.gov.pk/uploads/reports/APBL.pdf.

35. Imran $M$. Child rights committee to be formed in slums of Islamabad. The News International [Internet]. 2018 Oct 13 [cited 2019 Aug 23]:[National p.]. Available from: https://www.thenews.com.pk/print/380166-childrights-committee-to-be-formed-in-slums-of-islamabad.

36. Task Force on Social Safety Nets, Government of Pakistan. Social Safety Nets in Pakistan: A Way Forward
[Internet]. Pakistan: Benazir Income Support Programme; 2016 [cited 2019 Aug 5]. Available from: http://bisp.gov.pk/wp-

content/uploads/2016/07/Program_Details_Appendix. pdf.

37. Government of Pakistan. Ehsas Programme: Prime Minister's Policy Statement [Internet]. Pakistan: Government of Pakistan; 2019 [cited 2019 Jul 4]. Available from: http://www.pakistan.gov.pk/ehsaasprogram.html.

38. Islamabad Police Establishes Women and Child Protection Centre. Pakistan Today [Internet]. 2018 Jan 29 [cited 2019 Aug 23]:[City p.]. Available from: https://www.pakistantoday.com.pk/2018/01/29/isla mabad-police-establishes-women-and-child-protectioncentre/.

39. Government of Pakistan. Curriculum for Early Childhood Care and Education 2017 [Internet] Islamabad: Ministry of Federal Education \& Professional Training, Islamabad; 2017 [cited 2019 Aug 23]. Available from: http://moent.gov.pk/userfiles1/file/ECCE (22-0917).pdf.

40. Pakistan Bureau of Statistics. Population By Selective Age Group [Internet]. Pakistan: Pakistan Bureau of Statistics; 2019 [updated 2019 Aug 23; cited 2019 Aug 24]. Available from: http://www.pbs.gov.pk/sites/default/files//tables/P OPULATION BY SELECTIVE AGE GROUPS.pdf. 